\section{Sustainable Urban Tourism: In- volving local Agents and Part- nerships for New Forms of Governance (SUT-Governance) Project Legacy and the New Challenges}

\author{
by Krassimira Paskaleva-Shapira, ITAS*
}

\begin{abstract}
Urban tourism is a cluster of economic activities with significant socio-economic and environmental consequences on the individual cities. The principal aims of the SUT Governance project were to develop, validate, and deploy a general framework for urban sustainable tourism partnerships between researchers, city officials, tourism stakeholders, and community representatives and to elaborate and promote innovative forms and instruments of local governance involving the principles of sustainability and participatory decision making. Detailed field work was carried out in four European countries: Austria, Bulgaria, Greece, and Germany.
\end{abstract}

\section{Pursuing multi-partner solutions to complex urban tourism challenges: The legacy of the "SUT-Governance" project}

Europe's cities and towns contain a rich cultural heritage. Yet, maintaining this heritage presents many challenges, including dealing with the adverse environmental and social impacts of mass tourism. Demands from urban tourism alike are high and growing, hence the pressures and problems associated with the management of the sector have to be systematically tackled by all parties concerned. In their quest to further foster democracy and community prosperity, local authorities must seek tighter relations with a wide range of actors so the necessary political and operational consensus can be achieved to tackle problems successfully in benefit of all residents. Developing and operating publicprivate cooperations between the concerned parties is thus fundamental to effective urban governance of sustainable tourism. Achieving this involves advancing knowledge and practice about the types of partnerships that can be formed to promote urban sustainable tourism; the roles of government and other stakeholders; how local governments can apply such partnerships to long-term local tourism management and development; and the critical issues and challenges to local governments seeking to create such partnerships (Paskaleva-Shapira 2003).

The principal aim of the international research and policy project "Sustainable Urban Tourism: Involving local Agents and Partnerships for New Forms of Governance" (SUTGovernance) was to develop, validate, and deploy a general framework for urban sustainable tourism partnerships that is applicable to a variety of urban municipal contexts by drawing on detailed field work in four European countries: Germany, Austria, Greece and Bulgaria. The broader goal of the project was to elaborate and promote innovative forms and instruments of local governance to improve urban tourism development involving the principles of sustainability and participatory decision-making.

This three-year initiative, carried out between June 2000 and August 2003, was an international collaborative effort lead by the Forschungszentrum Karlsruhe GmbH (Germany) involving the University of Economics and Business Administration and Regional Consulting Ziviltechniker, $\mathrm{GmbH}$ in Vienna (Austria), Aristotle University of Thessaloniki (Greece), and the Veliko Turnovo University in Bulgaria. The study was part of the Key Action 4 "City of Tomorrow and Cultural Heritage" of the "Energy, Environment and Sustainable Development" Program within the "Fifth Framework Program" of the European Union.

2 Seeking effective results and innovation: The research and policy implications for sustainable urban tourism in Europe

The European dimensions of the "SUTGovernance" initiative are evident with respect to the six fold European concerns for Sustainability, Competitiveness, Governance, Local Agenda 21, Innovation, and Enlargement. Several project outputs are expected to add value to the immediate and mid-term strives in these areas: "Framework report: influences on decision-making" (enhanced research and policy approach of sustainable urban tourism); "Country context assessment report" (new systematic knowledge of policy and practice in SUT on different levels and 
actor institutions in the study countries); "Partnership cases: cross-case analysis and indicators of success" (innovative management and development tool for SUT); Final Project Conference (broad technology transfer of project results through a large number of representatives of local, national, and European stakeholders of tourism and urban development) and the "Final Technical Report" (a userfriendly project report summarizing the policy and development methodology and the benchmarking technique (basic steps of success) of starting and implementing successful multistakeholder partnerships for SUT).

Four project deliverables, however, will be of particular importance to innovation of policies in the strategic efforts of the European cities and the Community to Promote European-wide Sustainable Development, Endorse Governance, Achieve a Balanced Spatial Development, and Develop Citizens' Networks and Participation: (i) The "Set of European 'Best Practice' Partnerships for Sustainable Urban Tourism" for others to learn and improve practice (ii) The "Unified Framework Model for Effective SUT Partnerships" for improving tourism management and promoting local governance (iii) The "SUT Partnership Benchmarking Method and Tool" for assessing practice, measuring success and improving performance of existing or planned collaborative initiatives in tourism and (iv) The finally endorsed "European Platform and Forum" for enforcing further governance for sustainable urban tourism in our cities.

The longer-term implications of the project, however, are particularly evident with the systematic set of concepts, methodological approaches and policy recommendations established by "SUT-Governance" in an effort to promote Governance of Sustainable Urban Tourism in Europe:

Sustainable urban tourism (SUT) is a holistic, equitable, and future-oriented development strategy, part of the wider Urban Sustainable Development Agenda.

Operationalisation of SUT requires recognition of two fundamental principles imbedded in the sustainability-induced "integrated development" paradigm: (i) Sustainable tourism implies sustainable ends (outcomes and impacts of tourism products and services) and (ii) Sustain- able tourism involves effective delivery means (strategic policymaking and implementation).

Policy for sustainable urban tourism demands working approaches, i.e. SUT must be viewed as a consistent and continuous development strategy ensuring the balance of the present benefits of tourism with the future opportunities of the host community. Therefore SUT must be taken as a (i) policy option with communitycentred objectives and (ii) process of governing which has to be sustained in the life of the community. As such, SUT must (i) affect urban policy and development, considering both, industry and community long-term progress and (ii) account for both tourism product and its sustainability implications (direct and indirect).

Implementation of SUT calls for a multistakeholder approach to deal with the multifunctional nature of policies and actions, build consensus and share the responsibilities, risks and benefits from urban tourism in context of Urban Governance (taken as relationships and collaborative actions between urban actors to plan and manage the city affairs aiming at fostering democracy and community prosperity and involving government, private sector, and civil society).

Effective facilitation of multi-actor collaboration in SUT requires public-private partnerships. The latter can provide for, among others, enhanced tourism resources and services responsive to human needs; broad based sustainability gains; utilisation of community and business links and capacities; increased effectiveness and efficiency of local organisations; reduced conflicts, boosted trust and actor confidence; improved public policy and greater policy legitimacy; collective responsibility for planning, decision-making, problem solving, and project implementation and evaluation; community dialogue; responsible, engaged and involved locals and tourists; and combating local inequalities and fostering social inclusion. Therefore, partnerships must become a key principle of quality management of public services in city tourism towards urban sustainability and more local democracy.

Success of SUT partnerships depends on the efficacy of the (i) partnership process (ii) tourism activity and its implementation and (iii) activity resolutions for a long term and far reaching community sustainability 
Both, "development" and "marketing" tourism partnerships can promote sustainable community development, one, by increasing and effectively managing the use and increase of the local tourism "stock", and two, by sustaining and enhancing the partnership process and culture in the locality.

Implementation opportunities for SUT partnerships are multiple and can improve the urban built, natural environment, social fabric, human behaviour, and the overall local capacities.

Benchmarking SUT partnerships is key to improving collaborative practices and must become a consistent part of tourism quality management in the cities.

By and large, the project's results will assist a wide number of tourism decision-makers and stakeholders in their efforts to improve urban sustainability and governance in the European cities: Urban administrators and authorities, tourism businesses and organizations, academics and researchers, European and international policy-makers, civil society, tourists and consumer groups. Thanks to "SUT-Governance", public administrations in particular can begin making more informed choices and decisions about the opportunities and the potentials that partnership collaborations offer for improving the overall urban environment and the citizens' quality of life. A joint multi-actor action, however, is the recipe for success.

\section{Leading a multi-actor international con- sortium: The key role of ITAS in the strive to success}

By a wide recognition, the ITAS team, involving Krassimira Paskaleva-Shapira, Reinhard Coenen and Tobias Woll, played a critical role in leading the "SUT-Governance" Project success. The coordinator's contribution was key to both Project Organization and Study Development. In particular, ITAS was central to the project facilitation, implementation, and the successful completion. Its role in project administration, management and coordination, is much to be noted as well - the regular, comprehensive, and timely reporting was given a deserved credit by the Commission. To disseminate broadly the activities, implement the project results, and reach out to the wider pub- lic were of central attention to the team. Facilitating the six national workshops and the four partner city concept mapping exercises, participating in the EC "City of Tomorrow" cluster meetings and workshops, developing the project website, announcing in the media, engaging in European electronic expert and email groups, participating in conferences, and promoting a number of spill-off research initiatives are all to be mentioned here.

Yet, the distribution of more than 200 copies of the Final Technical Report to disseminate the methods, the results, and the policy recommendations of the project to the all-participating localities and publicly to the wider set of stakeholders and interested parties in Europe, deserves a special recognition. The Final Implementation Plan too, which informs interested party about the realizations and the exploitable potentials of the project results, was well received by the European Commission. In the end, the concluding Project Conference in Heidelberg (June 2003), which brought together 53 tourism and urban experts from Austria, Germany, Belgium, Bulgaria, Russia, United Kingdom, Spain, Greece, and Serbia to discuss innovative ideas of bridging science and practice in governance for sustainable urban tourism, was too, as in the words of many, a considerable achievement attributed to ITAS and the partners.

The spill-off projects and new initiatives arising from "SUT-Governance", however, are the genuine proof of the success of the effort: In 2002 ITAS engaged as a key partner in the "INTELCITY" EC IST RTD Roadmap Project (2002-03) and is now core to the newly commenced EC "Framework 6" projects "INTELCITIES" and "PICTURE" dealing with issues of sustainability, governance of intelligent cities, and cultural tourism and heritage in the Knowledge Society. Finally, the several ongoing EC FP6 bid developments in Smart Tourism, Tourism and European Governance and Citizenship, and Heritage e-Destinations promoted by ITAS are all aimed too at extending the legacy of "SUT-Governance" into the new realities and challenges of the future.

In Project Development, ITAS held a lead position during the entire project and particularly in setting up the conceptual approach, designing the work and implementing the results. Its role was especially strong in the initial phase 
of the initiative establishing the study framework in regard to agents and factors of success of participatory decision-making for sustainable tourism. ITAS was also leading in the final stages of the project - in the development and implementation of a Benchmarking Procedures and Tool allowing the urban authorities in 125 European cities to assess their performance and improve practices in developing participatory sustainable tourism in their communities. The on-line version of the Tool operating on the "SUT-Governance" website continues to provide tourism stakeholders with a free opportunity to self-assess practice and seek innovation.

In all these efforts, the contribution of Reinhard Coenen deserves a special recognition. Reinhard's role in all projects developments was indispensable and much valued by all partners. His part in facilitating and working with the cities of Heidelberg, Berlin KöpenickTreptow, Trier, Lübeck and the partnerships study cases in Germany was key driver of success in the entire project. Motivating and bringing the "SUT-Governance" Consortium together and inspiring new undertaking and projects were likewise much Reinhard's tribute.

\section{Working with multiple actors: The impor- tance of the participating cities and the SUT partnerships}

The success of the project has much depended on the close cooperation between the researchers, city officials, tourism stakeholders, and community representatives from the participating countries, cities and the partnership initiatives. The aim was to identify, elaborate, and validate a set of best practices for sustainable urban tourism, with an understanding of the conditions in which those practices were established in order to develop an integrated framework model of SUT Partnerships success.

In tourism, the social, economic and environmental impacts on the local communities are interrelated, overlapping and mutually reinforcing. Partnerships therefore appear essential in order to tackle the problems of local tourism, their causes and the externalities. This view must underpin urban policy for sustainable tourism as it has been done in urban regeneration, employment and social inclusion programs in the 1980s and more recently, in EU policies in support of local and regional development.

City authorities logically have a central role to play in promoting and sustaining collaborative partnerships. In view of the growing complexity of urban development today, it is becoming increasingly necessary to make all active participants in the urban environment, i.e. the urban decision makers, face up to their responsibilities and allow the citizens they represent have a say in the running of cities. Furthermore, in the cities, where local governments have usually strong influence and power, tourism industry is less fragmented and disunited, and community groups are more influential, the role of public administrations in uniting the stakeholders for the establishment of a longterm local development framework in which collaboration is a cornerstone to success, appears an ultimate necessity (Paskaleva-Shapira 2001).

To fulfil its Agenda, the "SUT-Governance" project carried out twelve Pilot and eight detailed SUT Partnership case studies in diverse European cities. Central to the research efforts were the eight "Best Practice" Partnerships for Sustainable Urban Tourism, two in each of the four collaborating cites - Graz, Heidelberg, Thessaloniki and Veliko Turnovo. These already established multi-actor collaborations in tourism marketing and management, sustainable tourism, urban renewal and regeneration, integrated local development, healthy communities, and regional integration were nominated based on their accomplishments in tourism, effective partnerships, sustainability, and favourable community impacts.

The partnership cases promoted by "SUTGovernance" demonstrate the practical ways in which communities; governments and the private sector are working together to improve tourism practices towards a better urban governance and long-term community prosperity. Other cities and communities in Europe and around the globe can learn from these successful solutions for sustainable tourism development of the urbanising world. The database and the analytical summary reports developed by the project can be used for providing analytical and policy framework, assessment of current trends, benchmarking practices, enhancing per 
formance, capacity building, networking, and technical cooperation in urban tourism activities.

\section{Out-living the "SUT-Governance" be- quest: Meeting the new challenges}

Participatory governance arrangements have emerged as new innovative tools in promoting the objectives of sustainability in many policy areas in Europe and across the world. Their effectiveness in the field of urban tourism, as this study suggests, depends upon both national frameworks and local contexts. Urban tourism is a cluster of economic activities with significant socio-economic and environmental consequences on the individual cities. This applies especially in tourism intensive cities generating a substantial part of their employment and income opportunities from tourism. The need to provide sustainable solutions to tourism related problems triggers the formation of participatory governance arrangements combining efficiency and democracy in innovative ways. The effectiveness of the latter in the area of urban tourism depends upon and varies according to the political culture and the specific socio-economic characteristics of the cities. However, the general trends are embedded in the specific national and local frameworks favouring particular combinations of actors and activities and forming country-specific and city-specific trajectories of sustainable tourism. As the interrelations at the European, the national and regional and/or local scale are being restructured under the strong pressure of globalisation, individual cities emerge as the most appropriate level for the implementation of the new ideas of participatory governance involving the networking of actors and the participation of a variety of stakeholders in specific types of partnerships, initiatives and policy making processes. Thus, "SUT-Governance" argues, the similarity of scope behind this mosaic of cultural diversity will strengthen the overall prospects of European cohesion (Kafkalas 2003).

Against this background, the "SUT-Governance" Consortium together with the participants of the Final Project Conference in Heidelberg 2003, in a joint Statement, have declared their personal and institutional commitment to promote a new Forum and Platform for dialogue and co-operation towards Enforcing Governance for Sustainable Urban Tourism in Europe.

The Statement followed on the Commission's strategic commitment to European Governance, Sustainable and Competitive Tourism and Integrated Urban Development. With it, the "SUT-Governance" team strived to further assist the process of developing European policies that have positive impact on cities and urban municipalities. The document set out the leading principles that can guide the relations among the tourism stakeholders in the urban environments towards sustainability and participatory decision-making and defined the scope of their dialogue. It overwhelmingly emphasised the importance of tourism for urban sustainability and governance and the building of dynamic, competitive, quality and participatory-based urban economies in Europe. Likewise, it reiterated the importance of efficient distribution of information, the coordination of activities and improved communication between the stakeholders concerned.

To achieve its goals, the Statement called for the creation of a European-wide Urban Governance Platform and Forum in which the city authorities are invited to play a major part. The focus need has to be placed on the need to enable innovation and collaborative multi-actor work in the spirit of local governance and overall community prosperity. Europe's tourism and urban development stakeholders are urged to establish a collaborative debate, engage in stimulating events, and plan for effective joint actions. The aim of the effort should be the establishment of an Urban Tourism Governance Framework and the development of Guidelines for delivery in the European cities.

The "SUT-Governance" team looks forward to taking part in a constructive debate and to forming the Agenda to reinforce the role of European sustainable tourism and innovative urban governance policies. We invite all key parties of urban tourism to join us in this Urban Tourism Governance Forum. For its part, the Institute for Technology Assessment and System Analysis in Karlsruhe will continue to support this process and the Agenda with the strategic goal of advancing the role of sustainable tourism for European Governance and Citizenship. 
* Since 1998 researcher at the Institute for Technology Assessment and Systems Analysis (ITAS).

\section{References}

Kafkalas, G., 2003: National frameworks for participatory sustainable tourism: Cultural diversity and European cohesion: Paper presented at the SUT Governance Project Final Conference, Heidelberg, Germany, 23-24 June; http://sut.itas.fzk.de

Paskaleva-Shapira, K., 2001: Innovative Partnerships for Sustainable Urban Tourism: Framework Approach. SUT-Governance project deliverable 2; http://sut.itas.fzk.de

Paskaleva-Shapira, K., 2003: SUT-Governance Final Project Report, August 2003; http://sut.itas.fzk.de

\section{Contact}

Dr. Krassimira Paskaleva-Shapira "SUT-Governance"-Coordinator Forschungszentrum Karlsruhe Institut für Technikfolgenabschätzung und Systemanalyse (ITAS)

Postfach 36 40, 76021 Karlsruhe

Tel.: +49 (0) 7247 / 82 - 6133

Fax: +49 (0) 7247 / 82 - 4806

E-Mail: paskaleva@itas.fzk.de

Internet: http://www.itas.fzk.de

\section{Durch den Rückspiegel \\ Nützliche Erfahrungen aus Planung, Organisation und Arbeitsablauf des Projekts „Global zukunftsfähige Entwicklung - Perspektiven für Deutschland“"}

von Uwe Klann und Joachim Nitsch, Deutsches Zentrum für Luft- und Raumfahrt

Das Projekt „Global zukunftsfähige Entwicklung - Perspektiven für Deutschland“, das in Zusammenarbeit mehrerer Institute der Helmholtz-Gemeinschaft deutscher Forschungszentren (HGF) von 1999 bis 2002 durchgeführt wurde, stellte hohe Anforderungen an Organisation und Management eines derart umfassenden transdisziplinären wissenschaftlichen Unternehmens. Am Beispiel des umweltökonomischen Gesamtmodells PANTA RHEI thematisiert der Beitrag konzeptionelle, methodische und kommunikative Aspekte, die bei der Kooperation der verschiedenen Arbeitsgruppen zu bewältigen waren. Es wird aufgezeigt, auf welchem Wege ein einheitliches Indikatorensystem inklusive einer für die Kommunikation unerlässlichen Reduktion auf Schlüsselindikatoren erstellt werden konnte, um darauf aufbauend die notwendige Konsistenz der Aussagen in und zwischen den unterschiedlichen Untersuchungsfeldern (Mobilität und Verkehr, Wohnen und Bauen, Ernährung und Landwirtschaft, Freizeit und Tourismus) zu erreichen. Der Bericht baut auf den Erfahrungen eines direkt „Betroffenen“ auf.

Die Technikfolgenabschätzung ist ebenso wie angewandte Arbeiten zur nachhaltigen Entwicklung auf einen transdisziplinären Ansatz angewiesen, der bekanntermaßen besondere methodische, kommunikative und organisatorische Schwierigkeiten birgt. Diese waren aufgrund des konzeptionellen Ansatzes besonders in dem letztes Jahr (2003) beendeten HGFVerbundprojekt „Global zukunftsfähige Entwicklung - Perspektiven für Deutschland“, zu überwinden.

In dem Projekt kooperierten Mitarbeiter des Instituts für Technikfolgenabschätzung und Systemanalyse des Forschungszentrums Karlsruhe (Federführung), das Deutsche Zentrum für Luft- und Raumfahrt (DLR) mit dem Institut für 